Bond University ePublications@bond

Sports Law eJournal

Faculty of Law

$11-12-2015$

\title{
Match and spot fixing: Challenges for the International Cricket Council
}

Chris Davies

James Cook University

Follow this and additional works at: http://epublications.bond.edu.au/slej

Part of the Entertainment, Arts, and Sports Law Commons

\section{Recommended Citation}

Chris Davies. (2015) "Match and spot fixing: Challenges for the International Cricket Council" ,, : ISSN 1836-1129.

http://epublications.bond.edu.au/slej/30 


\title{
Match and spot fixing: Challenges for the International Cricket Council
}

\begin{abstract}
Cricket is a sport that has been affected by both match and spot fixing over the last decade or so, with the former South African captain, Hansie Cronje and New Zealander, Lou Vincent, having admitted to be. Another New Zealander, Chris Cairns, is now facing perjury charges arising from his evidence at a defamation trial in which he denied being involved in fixing. Spot fixing was established against three Pakistan players during the 2010 tour of England that led to jail terms after the players failed to have their verdicts overturned in $R v$ Amir and Butt [2011] EWCA Crim 2914. It also involved appeals to the Court of Arbitration for Sport (CAS) after the players received lengthy bans from the International Cricket Council (ICC).CAS upheld these bans in CAS2011/A/2364 Salman Butt v ICC and CAS2011/A/2364 Mohammad Asifv ICC. Questions arise. Were there other incidents and why were these players more prone to approaches by bookmakers perhaps it is because players are some of the lowest paid in international cricket? This raises the issue whether the International Cricket Council (ICC) should consider establishing a 'minimum wage' for international cricketers. These incidents highlight that cricket, like other sports, must remain vigilant to the threat of matches being affected by match and spot fixing. The ICC has formed an Anti-Corruption and Security Unit (ACSU) and created an Anti-Corruption Code, in efforts to deal with these problems.
\end{abstract}

\section{Keywords}

cricket, match fixing, spot fixing, International Cricket Council, Court of Arbitration for Sport, integrity of sport

\section{Disciplines}

Entertainment, Arts, and Sports Law 


\title{
MATCH AND SPOT FIXING: CHALLENGES FOR THE INTERNATIONAL CRICKET COUNCIL
}

\author{
CHRIS DAVIES*
}

\begin{abstract}
Cricket is a sport that has been affected by both match and spot fixing over the last decade or so, with the former South African captain, Hansie Cronje and New Zealander, Lou Vincent, having admitted to be. Another New Zealander, Chris Cairns, is now facing perjury charges arising from his evidence at a defamation trial in which he denied being involved in fixing. Spot fixing was established against three Pakistan players during the 2010 tour of England that led to jail terms after the players failed to have their verdicts overturned in R v Amir and Butt [2011] EWCA Crim 2914. It also involved appeals to the Court of Arbitration for Sport (CAS) after the players received lengthy bans from the International Cricket Council (ICC).CAS upheld these bans in CAS2011/A/2364 Salman Butt v ICC and CAS2011/A/2364 Mohammad Asif v ICC. Questions arise. Were there other incidents and why were these players more prone to approaches by bookmakers - perhaps it is because players are some of the lowest paid in international cricket? This raises the issue whether the International Cricket Council (ICC) should consider establishing a 'minimum wage' for international cricketers. These incidents highlight that cricket, like other sports, must remain vigilant to the threat of matches being affected by match and spot fixing. The ICC has formed an Anti-Corruption and Security Unit (ACSU) and created an Anti-Corruption Code, in efforts to deal with these problems.
\end{abstract}

\section{INTRODUCTION}

The 2010 spot fixing case involving three Pakistani players - Salman Butt, Mohammad Asif and Mohammad Amir - showed cricket's vulnerability to this problem. More recently, two New Zealand players, Lou Vincent and Chris Cairns, have been implicated for different incidents. Vincent received a life ban $^{1}$ after confessing to fixing matches. Cairns currently is defending perjury charges relating to evidence he gave in a defamation case against Lalit Modi, former chairman of the IPL, who accused him of match fixing in the now defunct Indian Cricket League (ICL). These are far from the only incidents. Former South African captain, Hansie Cronje, was implicated back in 2000; and English County Cricket (ECC) has been targeted. ${ }^{2}$

This article examines the issues of match and spot fixing, focusing on the recent incidents involving specific players from Pakistan and New Zealand, the relevant Court of Arbitration for Sport (CAS) cases, and the International Cricket Council's (ICC) responses to the problem. First, it outlines the ICC's AntiCorruption Code for Participants (the Code).

\section{THE ICC CODE}

A feature of the Code is that it refers to, and covers, 'participants', not just players, with Article 1.4 defining participants to include selected cricketers as 'players', and 'any coach, trainer, manager, selector, team owner or official, doctor, physiotherapist or any other person... who is employed' as 'player support personnel.' Article 2 sets out the actual offences, the most relevant being:

Article 2.1.1

Fixing or contriving in any way or otherwise influencing improperly, or being a party to any effort to fix or contrive in any way otherwise influence improperly, the result, progress, conduct or any other aspect of any International Match or ICC event...shall amount to an offence by such Participant under the Anti-Corruption Code.

\footnotetext{
* Associate Professor, College of Business, Law and Governance, James Cook University, Australia.

1 Note that Vincent had already received a three year ban for failing to report approaches made to fix matches in the Bangaladesh League: 'Disgraced Vincent cops three-year ban' The Sydney Morning Herald, 20 June 2014, 37.

2 Sarah Harvey, 'Dirty dozen: investigator identify match-fix suspects', The Sydney Morning Herald, 17 May 2014, 59. 
Article 2.2.3

Ensuring the occurrence of a particular incident in an International Match or ICC event, which occurrence is to the Player or Player Support Personnel's knowledge the subject of a Bet and for which he/she expects to receive or has received any reward... shall amount to an offence by such Participant under the Anti-Corruption Code.

Article 2.2.4

Failing to disclose to the ACSU (without undue delay) full details of any approaches or invitations received by the Player or Player Support Personnel to engage in conduct that would amount to a breach of the Anti-Corruption Code...shall amount to an offence by a Player or Player Support Personnel under The Anti-Corruption Code.

While Article 2.1.1 is the main one, covering both match and spot fixing, Article 2.2.3 is also important, as it covers the odd bets, such as whether a player is wearing sun-glasses or short-sleeved jumper at a particular time. These may not have any effect on the match itself, but it is still best for the integrity of the game that they not be allowed. The inclusion of Article 2.2.4 also adds to the ICC's ability to try to combat corruption, since it places the onus on the player to report any approach, as it is now an offence not to do so.

I suggested that the formation of the Anti-Corruption and Security Unit (ACSU), presently headed by former senior police officer, Sir Ronnie Flanagan, has been just as significant. The operation of both the Code and the ACSU will be examined based on the recent incidents involving international players.

\section{THE INTERNATIONAL PLAYERS}

\section{New Zealand}

\section{Lou Vincent}

Although raised in Australia, Lou Vincent represented New Zealand in 23 Test matches and 102 One Day Internationals (ODIs) after making his debut in 2001. He scored a century on his Test debut, and was only one of two New Zealanders to do so, and is one of only 10 New Zealand players to score a double Test hundred with his 224 against Sri Lanka. ${ }^{3}$ He also played for Lancashire and Sussex in the ECC, the Chandigarh Lions in the ICL, and the Auckland Aces in the New Zealand Twenty 20 competition, as well as the Champions League. In 2013, Vincent voluntarily approached the New Zealand Cricket Players' Association, informing it that he had engaged in fixing matches. ${ }^{4}$

For Vincent, it all started with the end of his international career in 2007 and his involvement in the ICL, where he was first approached with offers of $\mathrm{A} \$ 53000$ to underperform by scoring 10-15 runs off 20-25 balls before getting out. Vincent, however, claims he never saw any of the money, ${ }^{5}$ a suggested reason being that the supposed fix did not work after 'accidentally' hitting a six while trying to get out. ${ }^{6}$ In 2008 he joined ECC side Lancashire, before playing for Sussex in 2011. Vincent has since identified three county matches during this period that were targeted, acknowledging that he received A\$71 800 to throw a match while playing for Sussex. ${ }^{7}$ Naved Arif, a Pakistani who played alongside Vincent at Sussex during this time has also received a life ban from the England and Wales Cricket Board (EWCB). ${ }^{8}$ New Zealand Cricket also confirmed that other affected matches were those in which Vincent played in South Africa for the Auckland Aces in the 2012 Twenty20 Champions League. ${ }^{?}$

In all, Vincent identified to the ACSU 12 matches from around the world where there had been matchfixing. ${ }^{10}$ It also appears that his teammates, although not involved, had their suspicions at the time, with

3 Paula Penfold, ‘Lou Vincent rebuilds life after cheating confession’ 3 July 2014. http://www.3news.co.nz/tvshows/3d/lou-vincent-rebuilds-life-after-cheating-confession2014070220\#axzz3r9zyh9pg.

4 Chris Hewett, 'Chris Cairns in court to defend charge,' The New Zealand Herald, 22 December 2014, $<$ http://www.nzherald.co.nz/nes/article>.

5 Paula Penfold, 'Lou Vincent rebuilds life after cheating confession', 3 July 2014, <http://www.3news.co.nz>.

6 'Match-fixer Lou Vincent tells of bat attack fears', The Australian, 3 July 2014, $<$ http://www.theaustralian.com.au/sport/cricket>.

7 Sarah Harvey, 'Dirty dozen: investigator identify match-fix suspects', The Sydney Morning Herald, 17 May 2014, 59.

8 Andy Wilson, 'Lou Vincent banned from cricket for life after admitting to match-fixing', The Guardian, 1 July 2014 $<$ http://theguardian.com/sport $>$.

9 Sarah Harvey, 'Dirty dozen: investigator identify match-fix suspects', The Sydney Morning Herald, 17 May 2014, 59.

10 Ibid. 
former New Zealand Test fast bowler, Ian O'Brien, stating that he knew Vincent 'had been up to no good'. ${ }^{11}$ O'Brien went on to state that while on tour with New Zealand he and his teammates had watched some of the ICL matches and had become 'aware that something was not right.' He went to say that it was 'some of the most unbelievable cricket,' describing it as being 'obvious what was going on: leaving or padding up to straight ones, run outs by massive distances in curious circumstances, batsmen playing out maidens'. ${ }^{12}$ However, former England captain, Andrew Strauss, has praised Vincent for working with the ACSU, stating he had given cricket authorities 'something to work with against a cancer in the game'. Strauss went on to state that Vincent had a key role to play 'in trying to get to the bottom of match fixing's tangled web'. ${ }^{13}$

While Vincent's decision to come clean of his involvement has enabled him to move on, for former teammate, Chris Cairns, the matter is still far from resolved.

\section{Chris Cairns}

During his international career with New Zealand, Cairns proved himself to be one of the finest Test allrounders in the world, scoring over 3320 runs at an average of 33.5 and taking 218 wickets at 29.4 in 62 Tests. He had an equally impressive record in his 215 ODI's, taking 201 wickets and scoring 4950 runs. ${ }^{14}$ Like Vincent, there has been no suggestion of any wrongdoing in regard to his international career, but accusations have been made about his time in the ICL.

These accusations first surfaced when Lalit Modi, former chairman of the IPL, made an 'unequivocal allegation' on Twitter in January 2010, in regard to Cairns being involved in match fixing. This tweet had then been placed on the cricket website, Cricinfo, though it was removed when Cairns complained, with Cricinfo also issuing an apology. ${ }^{15}$ Modi refused to make an apology, with Cairns then successfully suing him for defamation and receiving $£, 90000$ in damages, with Modi also facing up to $f 1.4 \mathrm{~m}$ in legal costs. ${ }^{16}$ Cairns, however, has been charged with perjury over the defamation case after some of the evidence that Vincent provided to the ACSU indicated Cairns' involvement, with the criminal trial to take place in October $2015 .{ }^{17} \mathrm{He}$ is also facing a civil action from Modi to recover the $f, 90000$ damages. ${ }^{18}$

A prison sentence can follow a finding of perjury. Three Pakistan players have already served prison terms for their involvement in match fixing. Concerns have also emerged about the reliability of the evidence from Mazher Mahmood, the main witness in the case.

\section{Pakistan}

\section{The players and incidents}

While the revelations regarding Salman Butt, Mohammad Asif and Mohammad Amir and the match fixing in England in 2010 are well known after the much-publicised trials and prison sentences, there were earlier incidents involving Pakistan players. In 2000, former captain, Salim Malik, received a life ban after three Australian players, Shane Warne, Mark Waugh and Tim May, accused him of offering bribes to underperform during Australia's 1994 tour of Pakistan. Malik's teammate, Ata-ur-Rehman, also received a life ban; while in 2010 Danish Kaneria was likewise given a life ban after being involved in setting up a fix in the ECC. ${ }^{19}$

Butt played for Pakistan from 2003-10, becoming captain in 2010, with Asif and Amir being the two opening bowlers on the 2010 England tour. Amir was 18 at the time of the alleged fixing at the Oval and Lord's cricket Tests. At the Oval Test the fixing allegations involved the batting out of a maiden by Butt, while at Lord's the fix involved the deliberate bowling of no-balls 'on order', that is, on a given ball of a given over. The 'fixer' had been Mazhar Majeed who was exposed by investigative journalist, Mazher

11 Peter Lalor, 'We knew fixer was up to no good', The Australian, 19 May 2014, 32.

Ibid.

13 Sarah Harvey, 'Dirty dozen: investigator identify match-fix suspects' The Sydney Morning Herald, 17 May 2014, 59.

14 'Chris Cairns perjury trial: Brendan McCullum to testify, The Sydney Morning Herald, 18 October 2014

$<$ http://www.smh.com.au/sport/cricket>.

15 'Chris Cairns wins $f_{9} 90000$ libel damages over match fixing claims' The Guardian, 26 March 2012 $<$ http://www.theguardian.com/sport>.

16 Nick Hoult, 'Cairns cleared of match fixing', The Daily Telegraph (UK), 27 March 2012, S13.

17 Chris Hewett, 'Chris Cairns in court to defend charge,' The New Zealand Herald, 22 December 2014 $<$ http://www.nzherald.co.nz/nes/article>.

18 Lizzy Ammon, 'Ex-New Zealand all-rounder Chris Cairns charged with perjury.' The Guardian, 26 September 2014, $<$ http://www.theguardian.com/sport>.

19 'Wrong 'uns' The Sunday Times, 11 March 2012, 14. 
Mahmood, from now defunct News of the World. Mahmood had pretended to be a businessman named Moshin Khan and then paid $f_{150} 000$ to Majeed in return for organising the bowling of no-balls, with all the dealings being secretly filmed. Over a two day period at Lord's, it was alleged that 'Amir and Asif delivered the no-balls exactly as paid for'. ${ }^{20}$ Mahmood then claimed that they 'finally had evidence of the fixing racket'. 21

Butt, Asif, Amir, as well as Majeed, were subsequently charged with conspiracy to accept corrupt payments under s 1 of the Prevention of Corruption Act 1906 (UK), and conspiracy to cheat at gambling under s 42 of the Gambling Act 2005 (UK).22 At the criminal trial, Butt received a two year sentence, Asif, 12 months, ${ }^{23}$ while Amir received a six month sentence at the Feldham Young Offenders Institute. These sentences received a mix reception in the cricketing world; some, such as former Pakistan captain, Rashid Latif, publically stated that 'the sentences were just'. ${ }^{24}$ Others, however, such as The Guardian journalist, Stephen Moss, have questioned the need to send the players to jail, ${ }^{25}$ while former England captain, Michael Atherton, was critical of the need to send young Amir to a young offenders' institution. ${ }^{26}$ However, regardless of one's view, it now should be accepted that questions have recently been raised in relation to the reliability of Mahmood's evidence, given that prosecutors were forced to drop charges of alleged match-fixing by 13 English footballers due to the unreliability of the evidence given by Mahmood. It should also be noted that Mahmood has now been suspended by the paper he presently works for, The Sun on Sunday. ${ }^{27}$

Before the criminal trial, however, the three players faced an ICC Tribunal in regard to breaches of Articles 2.1.1, 2.2.3 and 2.4.2 of the Code; the matter being heard on January 6-11, 2011. It was held that Butt's charge under Article 2.1.1 was 'proved beyond reasonable doubt' in relation to the Lord's Test. ${ }^{28}$ Butt's alleged breach of Article 2.4.2 in relation to the approach to bat out a maiden over at the Oval Test was again held to have been proved beyond reasonable doubt. ${ }^{29}$ The Tribunal considered the News of the World recordings to be authentic, noting that Butt was the 'only person who could guarantee which bowler bowled, when and for how long. The success of the fix could not be ensured without Salman Butt's collaboration. ${ }^{30}$ The Tribunal then imposed a sanction of 10 years' ineligibility, five of which was a suspended pending no further breaches. ${ }^{31}$ However, given Butt's age, it was a sanction that ended his career. The Tribunal also held that Asif's alleged breach of Article 2.1.1 has also been proven beyond reasonable doubt, ${ }^{32}$ and imposed a seven year sanction, two years suspended on the condition of no further breaches. ${ }^{33}$ Amir was given a five year ban by the Tribunal, which he accepted. Butt and Asif, however, both appealed the decision to CAS.

\footnotetext{
Mazher Mahmood, 'How I broke the spot-fix scandal' The Australian, 7 November 2011, 41.

Ibid.

CAS 2011/A/2364 Salman Butt v International Cricket Council, [36].

R v Amir and Butt [2011] EWCA Crim 2914.

Wayne Smith, 'Spot-fixer scandals take on a new twist' The Weekend Australian, 11 February 2012, 41.

Ibid.

26 Mike Atherton, 'Frightened and confused: the young Pakistani trapped by the underworld' The Weekend Australian, 5 November 2011.

27 'Lack of evidence ends UK match-fixing case' The Australian, 16 January 2015, 31.

28 CAS 2011/A/2364 Salman Butt v International Cricket Council, [32]. Note that Article 3.1 states that under the Code, the standard of proof shall be whether the Tribunal is comfortably satisfied the alleged offence has been committed, bearing in mind the seriousness of the allegation that is being made. The standard of proof in all cases is greater than a mere balance of probability but less than beyond reasonable doubt.' It is interesting therefore that the Tribunal specifically refers to 'beyond reasonable doubt' which suggests that it was taking into consideration the seriousness of the allegations, and/or the fact it felt the case was that strong it had been proven beyond reasonable doubt. It should be noted that in its report into Lance Armstrong, USADA likewise referred to the case being proven beyond reasonable doubt. For more discussion on standards of proof within sport see Chris Davies, 'Doping in Sport: Landis, Contador, Armstrong and the Tour de France,' (2013) 25 Bond Law Review 66; Chris Davies, 'The Comfortable Satisfaction Standard of Proof Applied by the Court of Arbitration for Sport in DrugRelated Cases,' (2012) 14 The University of Notre Dame Australia Law Review 1.

29 CAS 2011/A/2364 Salman Butt v International Cricket Council, [33].

30 Ibid [34].

1 Ibid [35].

32 CAS 2011/A/2362 Mohammad Asif v International Cricket Council, [18].
}

3 Ibid [19]. 


\section{The Court of Arbitration for Sport decisions}

Butt's appeal was based on the length of the sanction, rather than liability, with the CAS Panel stating it would apply the ICC Code and where applicable, English law. Article 7.3.3 of the ICC Code states that 'the governing law shall be English law, unless otherwise agreed'. ${ }^{34}$

It was noted by the Panel that it only had authority to reduce a minimum sanction in exceptional circumstances, such as it not being just or proportionate, referring to an earlier CAS decision, Puerta, ${ }^{35}$ and also English law as authority. ${ }^{36}$ Butt's submission was that CAS can also modify a minimum sanction which is imposed irrationally on the basis that such a situation would also be exceptional. CAS then stated that the threshold for showing irrationality was high, namely it must be shown that the decision taken was obviously or self-evidently unreasonable or perverse. ${ }^{37}$

Butt argued it was irrational for him to have been sanctioned for five years, the minimum allowed under Article 2.1.1, when Article 2.2.3 only had an ineligibility minimum period of two years. It was held however that the two Articles captured 'distinct infringements of varying gravity', ${ }^{38}$ Article 2.1.1 intending to capture match and spot fixing, Article 2.2.3, the betting on aspects that would not actually impact on the game, such as what type of jumper the player would be wearing at a particular time of the match. ${ }^{39}$ The Panel then pointed out that the five year sanction was significantly shorter than equivalent sanctions in other sports, and held that the sanction imposed on Butt was not irrational. ${ }^{40}$ In regard to Butt's argument that the 'Tribunal imposed a sanction, which was evidently and grossly disproportionate', 41 the view of the Panel was that it 'could reasonably be described as lenient.' This was because he was captain of Pakistan and the orchestrator of the no-balls during the Lord's Test. ${ }^{42}$

The main submissions of Asif's appeal, meanwhile, were that his rights under Article 6 of the European Convention on Human Rights had been violated by the ICC, and that the evidence relied upon by the ICC was unlawful since it had been 'obtained in contempt of court.' ${ }^{43}$ It was also argued, inter alia, that the Tribunal had misdirected itself as to the standard of proof and 'lacked the requisite knowledge of cricket', while the circumstantial evidence showed he did not deliberately overstep the popping crease. ${ }^{44}$

However, during the CAS Hearing, Asif acknowledged he 'had a full and fair hearing', ${ }^{45}$ with the Panel further stating it was not satisfied 'there was any significant lack of due process' in the case. It then stated it had 'little doubt, if any, that a Tribunal consisting of three eminent jurists would have misdirected itself as to the nature of "beyond reasonable doubt" ', with the Panel also of the opinion that they had a 'good and sufficient knowledge of the game of cricket'. ${ }^{46}$ While it was accepted that Asif's no-ball was minor in comparison to that of Amir's, ${ }^{47}$ the Panel was satisfied he was not prone to overstepping, and 'would under normal conditions be capable of judging with some precision where his front foot would land.' ${ }^{48} \mathrm{It}$ was therefore held that Asif's 'submissions do not break the chain of circumstantial evidence or in any way undermine the reasoning contained in the [Tribunal's] Determination.' 49

While CAS upheld the ICC Tribunal's sanctions against both Butt and Asif, there were still other issues needing to be investigated by the ICC.

CAS 2011/A/2364 Salman Butt v International Cricket Council, [50].

CAS 2006/A/1025

CAS 2011/A/2364 Salman Butt v International Cricket Council, [61].

37 Ibid [62], citing CAS 2008/A/1574 which, it was noted, had in turn cited Associated Provincial Picture House Ltd v Wednesday Corporation [1948] 1 KB 223.

38 Ibid [68].

39 Ibid [67].

Ibid [70].

Ibid [71].

Ibid [74].

CAS 2011/A/2362 Mohammad Asifv International Cricket Council.

Ibid [25].

Ibid [42].

Ibid [44].

Ibid [56].

8 Ibid [59].

Ibid [69]. 


\section{The ICC's further investigations}

After the revelations regarding the Lord's Test, the ICC announced that it would investigate all of Pakistan's matches during 2010 against Australia and England. ${ }^{50}$ First, it should be noted that in his sentencing judgment for Amir, Justice Cooke accepted that there was evidence of fixing in the Oval Test, as well as the Lord's Test, for which he had pleaded guilty. ${ }^{51}$ It has also been revealed that deleted texts from Majeed show there had been conspiracies to spot fix aspects of Pakistan's tests against Australia in England in July 2010, prior to the tests against England. ${ }^{52}$ However, Australian opening batsman in that test, Simon Katich, has stated that the Australian players had no idea that any fix was on. ${ }^{53}$

The test earlier in the year at the Sydney Cricket Ground (SCG) where Pakistan lost, in a match they seemingly had won, came under scrutiny. Firstly, in its second innings Australia appeared as though it would struggle to make Pakistan bat again on the last day after starting the day eight wickets down, and at odds of 10-1 to win the test. However, a century by Michael Hussey, helped by dropped catches by wicketkeeper, Kamran Akmal, and supported by tailender, Peter Siddle, Australia managed to set Pakistan a modest 130 runs, which it failed to reach. The then head of the ACSU, Lord Paul Condon, stated:

We are satisfied that that was a totally dysfunctional tour from a Pakistani point of view, and that dysfunctionality in the dressing room led to players not performing well, and maybe making them potentially underperform deliberately. What we still need to establish is whether that has been because rival camps wanted to do captains down or potential captains, or whether it was something more serious, doing it for a financial fix. ${ }^{54}$

The author, who was present on the day, still has doubts about the integrity of that Test match. However, it is accepted that there is no direct evidence of fixing, and the author is aware of at least two Tests lost by Australia in very similar situations to that of Pakistan, namely the opposition struggling to avoid an innings defeat, managed to scrape a 130-150 run lead, before bowling Australia out for under that total. The two Tests in mind are the 1981 Headingly Test against England, and the 1994 SCG Test against South Africa, the former being now infamous for Australian players, including Dennis Lillee and Rodney Marsh, putting relatively small bets on England when bookmakers had it at 500-1. However, the ICC today would not consider the betting in the light-hearted way that it was at the time it was revealed.

What the 2010 SCG Test does illustrate is that such dramatic turnarounds are now viewed with suspicion for, as Smith points out, the spread of spot fixing raises suspicions over the 'most apparently innocent of incidents' such as an easy dropped catch. ${ }^{55}$ Akmal at the SCG in January 2010: bad day at the office, or allegedly paid to make the mistakes? While there is no direct evidence of the latter, it is worth noting that during the Butt and Asif trial the prosecutor claimed, 'that wicketkeeper Kamran Akmal was lucky not to be on trial too'. ${ }^{56}$

Thus, cricket must remain vigilant in regard to spot and match fixing. While the use of existing criminal offences can be used to bring charges against fixers, and this will be further enhanced by specific legislation, it is suggested that this provides more of a punitive regime rather than a preventative one. It is important that controls on match and spot fixing come from the ICC, with the formation of the ACSU and the creation of the Code being essential, and the ICC should be commended for the measures it has implemented.

So, let us turn to the following issues: whether the ICC could, or should, implement any further measures; the controversies surrounding Mohammad Amir's pending return; and the actual impact of match and spot fixing on cricket.

\section{DISCUSSION}

What is interesting about any match and spot fixing discussion is the evidence from some of the involved individuals that the agreed 'fixes' did not always work. Cronje, for instance, admitted that the games he was paid to fix did not produce the intended result, one reason being that the two other players involved,

50 Mazher Mahmood, 'How I broke the spot-fix scandal', The Australian, 7 November 2011, 41.

51 Nick Hoult, 'Amir: my friend Salman tricked me' The Daily Telegraph (UK), 20 March 2012, S8.

52 Peter Lalor, 'Aussie Lord's win stained,' The Australian, 3 November 2011, 40. Note that Australian was playing Pakistan in an 'away' series in 2010 due to security concerns about touring Pakistan. The ban on touring Pakistan is still in place and in 2014 Australia played its away matches against Pakistan in the United Arab Emirates (UAE).

53 Peter Lalor, 'We had no idea the fix was in: Katich', The Australian, 4 November 2011, 44.

54 Peter Lalor, 'Aussie Lord's win stained,' The Australian, 3 November, 2011, 40.

55 Wayne Smith, 'Spot-fixer scandals take on new twist', The Weekend Australian, 11 February 2012, 41.

56 Peter Lalor, 'We had no idea the fix was in: Katich', The Australian, 4 November 2011, 44. 
Gibbs and Williams, played well in the match, Thorpe et al pointed out that Gibbs 'could not resist the temptation of playing well', as apparently did Williams. ${ }^{57}$

Meanwhile, Vincent stated that he was paid to score 15-20 runs in the first few overs before getting out. However, as he points out on one occasion he danced down the wicket with the intention of getting out stumped, only to accidently hit the ball for six after 'the ball hit a footmark'. ${ }^{58} \mathrm{He}$ also stated that 'the mistake was compounded when he accidentally edged the next ball for four, ending his innings with an excessively high score for those who knew about the fix to make any money. ${ }^{59}$

What emerged in Butt's CAS appeal was that the suggested fix for the Oval Test was for him to play out a maiden in the first over of a Pakistan innings, with him to signal that intention by going down the wicket and prodding the pitch. However, when the time came in the Test for this fix, Butt did not give the signal, as he was concerned that he would not be able to control no runs being scored with a new ball and attacking fields. ${ }^{60}$ In a sport like cricket, there are many factors that cannot be controlled by one player - a batsman, for instance, being dependent on what the bowler delivers. In fact, the only things fully controlled by one player would be the deliberate bowling of no-balls and wides.

Thorpe et al define match fixing as 'the use of means to achieve a pre-determined outcome in a sporting contest,' and spot fixing as 'producing a pre-determined outcome in a specific part of a sporting contest'. ${ }^{61}$ While match fixing is undoubtedly the greater threat to the integrity of a sport, it should also be acknowledged that in a game of cricket, it is possible a spot fixing event may affect the outcome of a match. While it could be argued that the bowling of a few deliberate no-balls, like those of Asif and Amir in the Lord's Test, would not have an impact on the result of a Test match, there are at least two Tests where even one no-ball would have changed the result. ${ }^{62}$ Deliberately batting out a maiden over in a Test match is highly unlikely to influence its outcome. However, it could well do so in a one-day match, and even more so in a Twenty 20 match. Even the Vincent fixes that involved scoring a modest personal total at a moderate strike rate, could be crucial in the overall result of a Twenty 20 cricket. This is because the opening overs can be highly significant because of the field restrictions in place for the first six overs. Therefore it is possible a spot fixing incident could affect the actual outcome of a match, which is why, for the integrity of the game, it is essential the ICC treats them just as seriously as an attempt to fix the overall result.

One of the concerning aspects of the fix at Lord's was that an 18 year old player - new to the international scene - not only felt pressured into it by his captain, but also had nowhere to go to report in such a situation. However, during all the 2015 international matches at the SCG, prominent signs were displayed outside of the player's dressing rooms providing a phone number for the ACSU. ${ }^{3}$ Cricket Australia had banned mobile phones from the dressing rooms, another easy management strategy - which appears to have become standard ICC policy. No mobile phones signs were also in the dressing rooms at the SCG during the ICC's World Cup matches.

In his CAS appeal, Butt submitted:

Pakistani players were uniquely exposed and vulnerable to spot fixing (and the financial inducements which accompany it) because (1) their earnings were lower than certain other players, (2) they were not permitted to play in the Indian Premier League, and (3) Pakistan was unable to host home games due to the 2009 terrorist attacks in Lahore. ${ }^{64}$

Other international players have financial issues with their governing bodies; the Sri Lanka players, for instance, have, over recent years, had periods of several months during which they have not being paid by their governing body, Sri Lanka Cricket. The West Indies' 2014 tour of India was abandoned after the players boycotted the tour due to a pay dispute with the West Indies Cricket Board. It is time for the ICC to implement what could be considered another risk management policy in using some of its extensive

\footnotetext{
57 D Thorpe, A Buti, C Davies, S Fridman and P Jonson, Sports Law (2013, 2nd Edition, Oxford University Press) 249.

58 'Match-fixer Lou Vincent tells of bat attack fears', The Australian, 3 July 2014, $<$ http://www.theaustralian.com.au/sport/cricket>.

59 Ibid.

60 CAS 2011/A/2364 Salman Butt v International Cricket Council, [13].

61 D Thorpe, A Buti, C Davies, S Fridman and P Jonson, Sports Law (2013, 2nd Edition, Oxford University Press) 228.

62 There have been two tied Tests in cricket, Australia v West Indies in 1960, and Australia v India in 1986.

63 The author as a member of the Sydney Cricket Ground had access to the Members Pavilion where the players' dressing rooms are located.

64 CAS 2011/A/2364 Salman Butt v International Cricket Council, [71].
} 
television revenue money to institute a guaranteed, minimum wage for all international players. This will not prevent all fixing situations from occurring but it may help to curtail it.

While preventative strategies are important measures to combat the integrity threat that fixing represents, it is highly unlikely that fixing will be totally eradicated. It is essential that the ICC apply appropriate internal sanctions to those guilty of fixing. In Salmon Butt v ICC and Mohammad Asif v ICC, the CAS Panel noted that in many sports, life bans had been imposed as the appropriate penalty for corruption, ${ }^{65}$ which is why CAS considered Butt and Asifs bans to be lenient. While the ICC did not consider life-bans to be appropriate in these two cases, cricket authorities have certainly been willing to give life bans in other cases, such as those involving Cronje, Vincent, Malik and Kaneria. While it may seem to be of little consequence to someone like Vincent who did not report the matter until after his retirement, the ban includes any involvement in cricket, such as coaching, which can provide post-career employment and income for players.

The lightest penalty handed out by the ICC was the five year ban given to Mohammad Amir for his involvement in the no-balls at Lord's. However, it has to be accepted that there were mitigating circumstances in that case, namely, that he was an 18 year old placed under pressure by his captain, who also showed full remorse. What the relatively light penalty has created, however, is the so far unique situation of a player known to have been involved in fixing being allowed, firstly, back into domestic cricket, and then having a potential return to international cricket once his ban is completed in September 2015. At a relatively young age of 24 , he will then be eligible to resume his highly promising, and potentially extensive, international career. Sir Ronnie Flanagan, head of the ACSU, however, supported his return, stating he has been remorseful, has participated in all the ICC's anti-corruption programs, as well as assisted in the education programmes ${ }^{66}$ by disclosing all he knew. ${ }^{67}$ However, Amir's pending return has not been universally accepted with former Pakistan batsman, Ramiz Raja, speaking out against it, arguing 'there should be no way back for Amir'. ${ }^{68}$ Present Pakistan captain, Misbah-ul-Haq, has reportedly given him 'a cold reception' and rejected 'several opportunities to welcome Amir back to the fold'. ${ }^{69}$ Misbah-ulHaq has been 'tight-lipped about the prospect of his return to the national team'. ${ }^{70}$

A factor that has to be considered in a case like Amir's is that a player may not be actually selected at international level once their ban has been completed. While form is the main criteria for any international selection, other factors will potentially come into play, most notably team culture and moral. This may prove to be the case where too many other players may feel uncomfortable representing their country alongside someone who has admitted to fixing. The possibility of re-offending is another potential factor, though it is the author's opinion that this prospect is highly unlikely in Amir's case, given his clear remorse and co-operation with the ACSU.

It is also the author's opinion that there was a potential restraint of trade issue if Amir's ban had been any longer, for similar to any sanction imposed by a sport's governing body, it must be reasonable in the circumstances. Thus, there is an argument that any sanction longer than five years would not have been reasonable in Amir's case, given his age, the influence by an older captain and his clear remorse. They may be legal reasons also for allowing Amir back into cricket since, given all the circumstances, it could amount to an illegal restraint of trade not to do so.

Former England captain, Andrew Strauss, suggests cricket will probably never be able to fully eradicate fixing from the sport. ${ }^{71}$ The sport can be encouraged by the general risk management strategies implemented by the ICC, specifically sharing of information with the New Zealand and Australian governments for the 2015 Cricket World Cup. Further strategies for this event include the clampdown on in-play betting at the actual grounds, with those involved facing being banned from the remainder of the tournament. $^{72}$

Ibid [69].

6 Andrew Wu, 'Disgraced Amir given icy reception by captain', The Sydney Morning Herald, 9 February 2015, 52.

67 Huw Richards, 'Pakistani bad boy breaks new ground with return to pitch', The Sydney Morning Herald, 9 February 2015, 45.

68 Mike Atherton, 'It's not cricket unless compassion can override vindictiveness', The Weekend Australian, 14 February 2015, 43.

69 Andrew Wu, 'Disgraced Amir given icy reception by captain', The Sydney Morning Herald, 9 February 2015, 52.

70 Ibid.

71 Sarah Harvey, 'Dirty dozen: investigator identify match-fix suspects', The Sydney Morning Herald, 17 May 2014, 59.

72 'ICC out to stop live betting at World Cup matches,' The Weekend Australian, 7 February 2015. 


\section{CONCLUSION}

Cricket is not the only sport to be facing problems associated with match and spot fixing. It is also unlikely it can ever be totally eliminated. However, the measures implemented by the ICC, namely, the formation of the ACSU and the creation of an Anti-Corruption Code, form a framework where incidents can be dealt with, and appropriate sanctions be imposed. Although there have been cases where life bans are appropriate, the situation of Mohammad Amir is one where a lesser penalty was required, both on reasonableness grounds and also on restraint of trade grounds. While the author supports the risk management strategies implemented by the ICC, it is also suggested that creating a guaranteed minimum wage for international players could also ensure these often high profile players will not be as vulnerable to approaches for match or spot fixing. 